CARMONA, PAO; PINHEIRO, JB; AMARO, GB; SILVA, GO; PEIXOTO, JR; CARES, JE. 2020. Resistance sources to root-knot nematodes Meloidogyne javanica, M. incognita and M. enterolobii in sweet potato. Horticultura Brasileira 38: 126-133. DOI - http://doi.org/10.1590/S0102-053620200203

\title{
Resistance sources to root-knot nematodes Meloidogyne javanica, M. incognita and $M$. enterolobii in sweet potato
}

\author{
Paula Andrea O Carmona ${ }^{1} \mathbb{D}$; Jadir B Pinheiro ${ }^{2} \mathbb{D}$; Geovani Bernardo Amaro ${ }^{2} \mathbb{D}$; Giovani Olegario da \\ Silva ${ }^{3} \mathbb{D} ;$ José Ricardo Peixoto ${ }^{1} \mathbb{D}$; Juvenil Enrique Cares ${ }^{1 \mathbb{D}}$
}

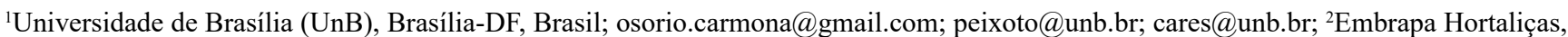
Brasília-DF, Brasil; jadir.pinheiro@embrapa.br; geovani.amaro@embrapa.br; ${ }^{3}$ Embrapa Hortaliças, EE de Canoinhas, Canoinhas-SC, Brasil; giovani.olegario@embrapa.br

\begin{abstract}
One of the main obstacles for food production in many developing countries, as in Brazil, is the damage caused by root-knot nematodes, mainly those belonging to the genus Meloidogyne. This study aimed to assess the resistance levels of 44 sweet potato genotypes to $M$. javanica, $M$. incognita race 1 and $M$. enterolobii. These researches were carried out in 2014, under greenhouse conditions in BrasíliaDF, Brazil. A completely randomized design with six replicates of one plant/plot/treatment was used. We determined the gall index (GI) and egg mass index (EMI) in the root system of each plant, the number of eggs and juveniles per gram of root with galls and the nematode reproduction factor. M. javanica was less aggressive and reproduced in only $9.09 \%$ of the evaluated genotypes; $M$. incognita race 1 was intermediate $(47.73 \%)$; whereas $M$. enterolobii was more aggressive, with a population increase in $79.55 \%$ of the genotypes. The genotypes CNPH 1200, CNPH 1219, CNPH 1292, CNPH 1392, CNPH 60 and 'Coquinho' were the most resistant to the three species and can be used in breeding programs for multiple resistance to root-knot nematodes.
\end{abstract}

Keywords: Ipomoea batatas, plant breeding, reproduction factor, genetic resistance.

\section{RESUMO}

Fontes de resistência aos nematoides-das-galhas Meloidogyne javanica, M. incognita e M. enterolobii em batata-doce

Um dos principais obstáculos para a produção de alimentos em muitos países em desenvolvimento, como no Brasil, é o dano causado por fitonematoides, principalmente os formadores de galhas, pertencentes ao gênero Meloidogyne. $\mathrm{O}$ trabalho teve como objetivo avaliar o nível de resistência de 44 genótipos de batata-doce a $M$. javanica, $M$. incognita raça 1 e $M$. enterolobii. O experimento foi realizado em 2014, em casa de vegetação, em Brasília-DF. Utilizouse o delineamento inteiramente casualizado, com seis repetições, constituindo-se de uma planta por tratamento. Foi determinado o índice de galhas (GI) e de massas de ovos (EMI) no sistema radicular de cada planta, quantificado o número de ovos e juvenis por grama de raiz e parte da raiz tuberosa com galhas e efetuado o cálculo do fator de reprodução dos nematoides. Verificou-se que $M$. javanica foi menos agressivo e se reproduziu em apenas $9,09 \%$ dos genótipos avaliados. $M$. incognita raça 1 foi intermediário, com 47,73\%; enquanto que $M$. enterolobii foi mais agressivo, com aumento populacional em 79,55\% dos genótipos. Os genótipos CNPH 1200 , CNPH 1219, CNPH 1292, CNPH 1392, CNPH 60 e 'Coquinho' foram os mais resistentes às três espécies avaliadas, podendo ser utilizados no melhoramento visando à resistência múltipla aos nematoides-das-galhas.

Palavras-chave: Ipomoea batatas, melhoramento genético, fator de reprodução, resistência genética.

\section{Received on July 29, 2019; accepted on March 27, 2020}

$\mathrm{T}$ he sweet potato (Ipomoea batatas), although being a rustic plant, hosts nematodes of the genus Meloidogyne. These nematodes cause great concern regarding production losses in the tropics, subtropics and warm regions all around the world (Atkinson et al., 2012; Bernard et al., 2017; Karuri et al., 2017).

In Brazil, the most important species in sweet potato cultivations are $M$. incognita and $M$. javanica (Charchar \& Ritschel, 2004; Chaves et al., 2013) and, according to Cervantes-Flores et al. (2002a), resistant genotypes to multiple species of Meloidogyne have been rarely recorded. However, M. enterolobii, synonym of M. mayaguensis, is gaining prominence due to its ability to infect plants that are resistant to other species of Meloidogyne (Carneiro et al., 2006a, 2006b), among them the sweet potato (EPPO, 2014; Rutter et al., 2019).

The root-knot nematodes can reduce absorbent roots, with reduction on foliage and growth of the sweet potato plant, besides predisposing to the formation of longitudinal cracks in the roots, affecting not only yield, but also quality, conservation and the visual appearance of the commercial product (Perry \& Moens, 2006; Bernard et al., 2017).

Several strategies have been used to control root-knot nematodes in sweet potato, among them the use of chemical nematicides, in countries where there 
are registered products. Although nematicides are effective, the cost and high toxicity difficult the viability of use. Therefore, the plant genetic resistance, whenever available, is the most efficient method of controlling nematodes, besides being economically sustainable and environmentally safe (Melo et al., 2011; Piedra-Buena et al., 2011; Gomes, 2014; Gomes et al., 2015; Bernard et al., 2017). Although being the genetic resistance of great importance, the integrated control management, also based on prophylactic actions, and biological control, could be more effective.

The aim of this study was to assess the levels of resistance of 44 sweet potato genotypes to $M$. javanica, $M$. incognita race 1 and $M$. enterolobii, to be used in breeding programs as resistance genes sources to root-knot nematodes.

\section{MATERIAL AND METHODS}

The experiments were conducted between December 17, 2013 and April 14, 2014, in a greenhouse at Embrapa Hortaliças, Brasília-DF, Brazil (155' 44"S, 4808'29"W, 999 m altitude), whose climatic classification according Köppen, is tropical savanna with rain concentration in summer and dry in winter.

Forty four sweet potato genotypes, from the Active Germplasm Bank of Embrapa Hortaliças, were evaluated for resistance to $M$. javanica, $M$. incognita race 1 , which is the nematode race that most occurs in vegetables cultivations in Brazil, including sweet potato, and M. enterolobii. The genotypes were chosen due to its superior characteristics and potential to become new cultivars, and not yet characterized to nematode resistance. For each species of nematode, an independent experiment was installed, using a completely randomized design with six replications. Each experimental plot consisted of one plant grown in a 2-L plastic pot, containing substrate on the proportion 1:1:1:1 of subsurface soil (a clay Oxisol, typically encountered in the Savanna Biome region in Brazil), washed sand, cow manure and carbonized rice husk mix, autoclaved at $121^{\circ} \mathrm{C}$ for $60 \mathrm{~min}$. We added to $300 \mathrm{~g}$ of this mixture 300 g N-P-K, 4-30-16 formulation, and $3,000 \mathrm{~g}$ of calcined dolomitic lime. The seedlings were obtained from healthy vines with four intermodal buds from each genotype, and planted individually.

The identification of the rootknot nematodes, $M$. javanica, $M$. incognita race 1 and $M$. enterolobii, was accomplished by morphological examination of the perineal region of adult females and comparison with taxonomic descriptions and keys of Yang \& Eisenback (1983); Rammah \& Hirschmann (1988) and Eisenback \& Hirschmann-Triantaphyllou (1991). To analyze the phenotype of esterase isozyme we used the technique proposed by Carneiro \& Almeida (2001). The Meloidogyne incognita race was identified according to the differential host test of Taylor \& Sasser (1978).

The treatments consisted of clones CNPH 02, CNPH 05, CNPH 08, CNPH 41, CNPH 46, CNPH 53, CNPH 56, CNPH 59, CNPH 60, CNPH 66, CNPH 69, CNPH 80, CNPH 1192, CNPH 1195 , CNPH 1197, CNPH 1200, CNPH 1202, CNPH 1208, CNPH 1216, CNPH 1219, CNPH 1220, CNPH 1221, CNPH 1232, CNPH 1292, CNPH 1298, CNPH 1310, CNPH 1344, CNPH 1357, CNPH 1358, CNPH 1361, CNPH 1365, CNPH 1392, CNPH 1393, CNPH 1394, CNPH 1796, CNPH 1805 and CNPH 1809, besides cultivar Rainha and the commercial cultivars Brazlândia Rosada, Brazlândia Branca, Brazlândia Roxa, Coquinho, Princesa and Beauregard. The sweet potato cultivars Brazlândia Roxa and Brazlândia Branca were used as standards of resistance and susceptibility, respectively for $M$. javanica and $M$. incognita race 1, (Charchar \& Ritschel, 2004; Marchese et al., 2010; Massaroto et al., 2010). In addition, the tomato 'Santa Cruz' (Solanum lycopersicum) was used as susceptibility standard.

Thirty days after planting the vines, eggs and juveniles of second stages (J2) were extracted from the tomato 'Santa Cruz' roots, inoculated previously with each species to be evaluated, according to methodology of Boneti \& Ferraz (1981). After the calibration, the inoculum was distributed over the soil, around the plants, with a concentration equivalent to 5,000 eggs $+\mathrm{J} 2 /$ plant . Plants were irrigated daily, and about one month after inoculation, side dressing was carried out using $3 \mathrm{~g}$ of Osmocote ${ }^{\circledR}$ (19-06-10 N-P-K) per liter of substrate.

Plants were harvested 80 days after inoculation, and determined the gall index (GI) and egg mass index (EMI) in the root system of each plant, according to the grades scale proposed by Taylor \& Sasser $(1978)(0=$ roots without gall or egg masses; $1=$ presence of 1 to 2 galls or egg masses; $2=$ presence of 3 to 10 galls or egg masses; $3=$ presence of 11 to 30 galls or egg masses; $4=$ presence of 31 to 100 galls or egg masses and $5=$ presence of more than 100 galls or egg masses on the root system). The final population of the nematodes in the root system and in the portions of the tuberous roots with galls, were also quantified, extracting the eggs and nematodes using the method of Boneti \& Ferraz (1981). The final population $(\mathrm{Fp})$ was quantified, counting the eggs and $\mathrm{J} 2$ under an optic microscope. The results were divided by the fresh weight of the root and the part of the tuberous roots with galls and expressed as eggs $+\mathrm{J} 2$ per gram of root (FWRG). The nematode reproduction factor $(\mathrm{Rf}=\mathrm{Fp} / \mathrm{Ip})$ was calculated by dividing the final and initial populations (inoculated). Genotypes presenting Rf less than 1 were considered resistant, and susceptible those presenting $\mathrm{Rf}$ greater or equal to the unit (Oostenbrink, 1966).

The data were transformed to $\sqrt{\mathrm{x}+1}$, to meet the assumptions of normal distribution and homoscedasticity, being presented the original values.

Data were subjected to a one-way analysis of variance (ANOVA), for each characteristic, and means were grouped using the Scott-Knott clustering test at a significance level of 0.05 , using Genes software (Cruz, 2013).

\section{RESULTS AND DISCUSSION}

We observed a predominance of variation of genetic order in relation to the environmental variation for most of 
the evaluated characters, for the different species of nematodes, according to values higher than the unit for the rate between the genotypic and experimental coefficients of variation $(\mathrm{CVg} / \mathrm{CV})$, indicating favorable situation for the characterization of the resistance levels of the genotypes evaluated in the experiments (Tables 1, 2 and 3).

\section{Meloidogyne javanica}

Most genotypes (CNPH 02, CNPH 05, CNPH 08, CNPH 41, CNPH 46, CNPH 53, CNPH 56, CNPH 60, CNPH 66, CNPH 69, CNPH 80, CNPH 1195 , CNPH 1197, CNPH 1200, CNPH 1202, CNPH 1208, CNPH 1216, CNPH 1219, CNPH 1220, CNPH 1221, CNPH 1232, CNPH 1292, CNPH 1298, CNPH 1310, CNPH 1344, CNPH 1357, CNPH 1358, CNPH 1361, CNPH 1365, CNPH 1392, CNPH 1393, CNPH 1394, CNPH 1796, CNPH 1805, 'Rainha', 'Princesa', 'Brazlândia Rosada', 'Coquinho', 'Brazlândia Roxa' and 'Brazlândia Branca') were resistant to $M$. javanica (Table 1). 'Beauregard' and the clones CNPH 1192, CNPH 1809 and CNPH 59 were susceptible, being the last the best host among the evaluated genotypes, presenting the highest values for gall index, egg mass index and number of eggs $+\mathrm{J} 2$ per gram of root and in the portions of tuberous roots with galls, in addition to the highest reproduction factor (17.26).

Cervantes-Flores et al. (2002b) evaluated 26 sweet potato genotypes and also verified that most $(88.46 \%)$ were resistant to M. javanica, while the cultivar Beauregard was susceptible. Gomes (2014) also observed resistance of the sweet potato 'Brazlândia Branca' to this nematode.

Silveira \& Maluf (1993) evaluated 36 sweet potato clones regarding the resistance to $M$. javanica and identified 23 resistant materials. These authors also verified that the cultivars Brazlândia Roxa, Brazlândia Rosada and Coquinho were resistant. However, the cultivars Brazlândia Branca and Princesa, found being resistant in this research, in that study were considered susceptible.

Charchar \& Ritschel (2004) verified that $85.99 \%$ of 357 sweet
Table 1. Reaction of sweet potato genotypes to infection by Meloidogyne javanica. Brasília, Embrapa, 2019.

\begin{tabular}{|c|c|c|c|c|c|}
\hline Genotype & GI & EMI & Rf & Reaction & FWRG \\
\hline CNPH 56 & $0.33 \mathrm{e}$ & $0.33 \mathrm{e}$ & $0.00 \mathrm{~d}$ & $\mathrm{R}$ & $0.00 \mathrm{e}$ \\
\hline CNPH 1361 & $0.00 \mathrm{e}$ & $0.00 \mathrm{e}$ & $0.00 \mathrm{~d}$ & $\mathrm{R}$ & $0.00 \mathrm{e}$ \\
\hline CNPH 1394 & $0.33 \mathrm{e}$ & $0.17 \mathrm{e}$ & $0.00 \mathrm{~d}$ & $\mathrm{R}$ & $0.00 \mathrm{e}$ \\
\hline CNPH 08 & $0.00 \mathrm{e}$ & $0.00 \mathrm{e}$ & $0.00 \mathrm{~d}$ & $\mathrm{R}$ & $0.00 \mathrm{e}$ \\
\hline CNPH 1393 & $0.00 \mathrm{e}$ & $0.00 \mathrm{e}$ & $0.00 \mathrm{~d}$ & $\mathrm{R}$ & $0.00 \mathrm{e}$ \\
\hline CNPH 66 & $0.00 \mathrm{e}$ & $0.00 \mathrm{e}$ & $0.00 \mathrm{~d}$ & $\mathrm{R}$ & $0.00 \mathrm{e}$ \\
\hline 'Brazlândia Rosada' & $0.00 \mathrm{e}$ & $0.00 \mathrm{e}$ & $0.00 \mathrm{~d}$ & $\mathrm{R}$ & $0.00 \mathrm{e}$ \\
\hline CNPH 1197 & $0.00 \mathrm{e}$ & $0.00 \mathrm{e}$ & $0.00 \mathrm{~d}$ & $\mathrm{R}$ & $0.00 \mathrm{e}$ \\
\hline CNPH 1392 & $0.00 \mathrm{e}$ & $0.00 \mathrm{e}$ & $0.00 \mathrm{~d}$ & $\mathrm{R}$ & $0.00 \mathrm{e}$ \\
\hline CNPH 1195 & $0.00 \mathrm{e}$ & $0.00 \mathrm{e}$ & $0.00 \mathrm{~d}$ & $\mathrm{R}$ & $0.00 \mathrm{e}$ \\
\hline CNPH 1796 & $0.33 \mathrm{e}$ & $0.33 \mathrm{e}$ & $0.00 \mathrm{~d}$ & $\mathrm{R}$ & $0.00 \mathrm{e}$ \\
\hline CNPH 80 & $0.50 \mathrm{~d}$ & $0.00 \mathrm{e}$ & $0.00 \mathrm{~d}$ & $\mathrm{R}$ & $0.00 \mathrm{e}$ \\
\hline CNPH 1219 & $0.50 \mathrm{~d}$ & $0.50 \mathrm{e}$ & $0.02 \mathrm{~d}$ & $\mathrm{R}$ & $6.46 \mathrm{e}$ \\
\hline 'Coquinho' & $0.00 \mathrm{e}$ & $0.00 \mathrm{e}$ & $0.02 \mathrm{~d}$ & $\mathrm{R}$ & $12.08 \mathrm{e}$ \\
\hline 'Brazlândia Roxa' & $0.67 \mathrm{~d}$ & $0.17 \mathrm{e}$ & $0.02 \mathrm{~d}$ & $\mathrm{R}$ & $0.99 \mathrm{e}$ \\
\hline CNPH 1292 & $0.00 \mathrm{e}$ & $0.00 \mathrm{e}$ & $0.02 \mathrm{~d}$ & $\mathrm{R}$ & $6.89 \mathrm{e}$ \\
\hline CNPH 1358 & $0.00 \mathrm{e}$ & $0.00 \mathrm{e}$ & $0.03 \mathrm{~d}$ & $\mathrm{R}$ & $13.48 \mathrm{e}$ \\
\hline CNPH 1805 & $1.00 \mathrm{~d}$ & $1.00 \mathrm{~d}$ & $0.03 \mathrm{~d}$ & $\mathrm{R}$ & $11.57 \mathrm{e}$ \\
\hline CNPH 1365 & $0.00 \mathrm{e}$ & $0.00 \mathrm{e}$ & $0.03 \mathrm{~d}$ & $\mathrm{R}$ & $5.89 \mathrm{e}$ \\
\hline CNPH 05 & $0.17 \mathrm{e}$ & $0.17 \mathrm{e}$ & $0.03 \mathrm{~d}$ & $\mathrm{R}$ & $7.96 \mathrm{e}$ \\
\hline CNPH 1220 & $0.00 \mathrm{e}$ & $0.00 \mathrm{e}$ & $0.05 \mathrm{~d}$ & $\mathrm{R}$ & $68.73 \mathrm{e}$ \\
\hline CNPH 1298 & $0.17 \mathrm{e}$ & $0.17 \mathrm{e}$ & $0.07 \mathrm{~d}$ & $\mathrm{R}$ & $25.08 \mathrm{e}$ \\
\hline 'Rainha' & $0.00 \mathrm{e}$ & $0.00 \mathrm{e}$ & $0.08 \mathrm{~d}$ & $\mathrm{R}$ & $27.79 \mathrm{e}$ \\
\hline CNPH 1310 & $0.00 \mathrm{e}$ & $0.00 \mathrm{e}$ & $0.08 \mathrm{~d}$ & $\mathrm{R}$ & $20.34 \mathrm{e}$ \\
\hline CNPH 02 & $0.00 \mathrm{e}$ & $0.00 \mathrm{e}$ & $0.10 \mathrm{~d}$ & $\mathrm{R}$ & $28.61 \mathrm{e}$ \\
\hline CNPH 60 & $0.50 \mathrm{~d}$ & $0.50 \mathrm{e}$ & $0.10 \mathrm{~d}$ & $\mathrm{R}$ & $54.35 \mathrm{e}$ \\
\hline CNPH 1357 & $0.00 \mathrm{e}$ & $0.00 \mathrm{e}$ & $0.12 \mathrm{~d}$ & $\mathrm{R}$ & $145.07 \mathrm{e}$ \\
\hline CNPH 1232 & $0.33 \mathrm{e}$ & $0.33 \mathrm{e}$ & $0.12 \mathrm{~d}$ & $\mathrm{R}$ & $38.39 \mathrm{e}$ \\
\hline CNPH 46 & $1.83 \mathrm{c}$ & $2.00 \mathrm{~b}$ & $0.15 \mathrm{~d}$ & $\mathrm{R}$ & $53.63 \mathrm{e}$ \\
\hline CNPH 69 & $0.17 \mathrm{e}$ & $0.50 \mathrm{~d}$ & $0.16 \mathrm{~d}$ & $\mathrm{R}$ & $31.15 \mathrm{e}$ \\
\hline CNPH 1221 & $1.33 \mathrm{c}$ & $1.17 \mathrm{~d}$ & $0.17 \mathrm{~d}$ & $\mathrm{R}$ & $25.23 \mathrm{e}$ \\
\hline CNPH 1216 & $0.83 \mathrm{~d}$ & $0.83 \mathrm{~d}$ & $0.22 \mathrm{~d}$ & $\mathrm{R}$ & $53.45 \mathrm{e}$ \\
\hline CNPH 1200 & $2.00 \mathrm{c}$ & $2.33 \mathrm{~b}$ & $0.27 \mathrm{~d}$ & $\mathrm{R}$ & $75.66 \mathrm{e}$ \\
\hline 'Brazlândia Branca' & $1.50 \mathrm{c}$ & $1.33 \mathrm{c}$ & $0.37 \mathrm{~d}$ & $\mathrm{R}$ & $104.34 \mathrm{e}$ \\
\hline CNPH 1208 & $1.67 \mathrm{c}$ & $1.67 \mathrm{c}$ & $0.40 \mathrm{~d}$ & $\mathrm{R}$ & $220.52 \mathrm{c}$ \\
\hline CNPH 41 & $1.67 \mathrm{c}$ & $1.50 \mathrm{c}$ & $0.53 \mathrm{~d}$ & $\mathrm{R}$ & $601.37 \mathrm{c}$ \\
\hline CNPH 1344 & $2.00 \mathrm{c}$ & $2.00 \mathrm{~b}$ & $0.58 \mathrm{~d}$ & $\mathrm{R}$ & $469.64 \mathrm{~d}$ \\
\hline CNPH 53 & $1.00 \mathrm{~d}$ & $1.00 \mathrm{~d}$ & $0.63 \mathrm{~d}$ & $\mathrm{R}$ & $262.80 \mathrm{c}$ \\
\hline CNPH 1202 & $1.50 \mathrm{c}$ & $1.67 \mathrm{c}$ & $0.75 \mathrm{~d}$ & $\mathrm{R}$ & $256.66 \mathrm{c}$ \\
\hline 'Princesa' & $3.33 \mathrm{~b}$ & $3.33 \mathrm{a}$ & $0.85 \mathrm{~d}$ & $\mathrm{R}$ & $268.32 \mathrm{c}$ \\
\hline CNPH 1192 & $2.50 \mathrm{c}$ & $2.50 \mathrm{~b}$ & $1.65 \mathrm{c}$ & $\mathrm{S}$ & $712.09 \mathrm{c}$ \\
\hline
\end{tabular}


potato accessions were resistant to $M$. javanica, including 'Brazlândia Roxa' and 'Princesa'. However, different from the present study, the cultivars Brazlândia Branca, Brazlândia Rosada and Coquinho presented susceptibility. These differences in the patterns of resistance can occur due to differences on the geographic origin of the isolates, which can result in isolates with greater or lesser degree of virulence, in addition to factors such as high temperatures during the test which can cause resistance loss of materials. Inoculum level or inoculum pressure can also influence, in addition to other factors such as pot size, date of evaluation, among other factors.

\section{Meloidogyne incognita}

Only clones CNPH 1358, CNPH 02, CNPH 1361 and CNPH 1202 did not present galls or egg mass in the root systems, caused by $M$. incognita race 1 (Table 2). Genotypes CNPH 1192, CNPH 1216, CNPH 1220, CNPH 1221, CNPH 1298, CNPH 1344, CNPH 1805 , CNPH 1809, CNPH 41, CNPH 53, CNPH 59, 'Princesa' and 'Brazlândia Branca', were statistically equivalent to tomato 'Santa Cruz', presenting the highest average indexes of galls and egg masses. Among them, the most susceptible sweet potato genotypes to this nematode were CNPH 1192, CNPH 1216 and CNPH 59, with the highest values of eggs $+\mathrm{J}_{2} / \mathrm{g}$ on roots.

According to the reproduction factor, $52.27 \%$ of the genotypes (CNPH 02 , CNPH 05, CNPH 08, CNPH 56, CNPH $60, \mathrm{CNPH} 69, \mathrm{CNPH} 1197, \mathrm{CNPH}$ 1200, CNPH 1202, CNPH 1219, CNPH $1232, \mathrm{CNPH} 1292, \mathrm{CNPH} 1310, \mathrm{CNPH}$ 1392, CNPH 1358, CNPH 1361, CNPH 1393, CNPH 1394, 'Brazlândia Roxa', CNPH 1796, 'Rainha', 'Coquinho' and 'Brazlândia Rosada') were classified as resistant to $M$. incognita race 1 . Clones CNPH 46, CNPH 66 and CNPH 1220, did not differ statistically from the previous ones and were only slightly infected. However, due to the reproduction factors greater than 1 , were classified as susceptible. Although being these genotypes not extremely resistant, if they have other superior characteristics, they could be tested to,
Table 1. continuation ...

\begin{tabular}{lccccc}
\hline Genotype & GI & EMI & Rf & Reaction & FWRG \\
\hline 'Beauregard' & $3.00 \mathrm{~b}$ & $3.00 \mathrm{a}$ & $2.30 \mathrm{c}$ & $\mathrm{S}$ & $874.93 \mathrm{c}$ \\
CNPH 1809 & $3.00 \mathrm{~b}$ & $3.00 \mathrm{a}$ & $2.78 \mathrm{c}$ & $\mathrm{S}$ & $324.10 \mathrm{~d}$ \\
CNPH 59 & $4.00 \mathrm{a}$ & $4.00 \mathrm{a}$ & $17.26 \mathrm{~b}$ & $\mathrm{~S}$ & $5298.9 \mathrm{~b}$ \\
Tomato 'Santa Cruz' & $5.00 \mathrm{a}$ & $4.17 \mathrm{a}$ & $94.31 \mathrm{a}$ & $\mathrm{S}$ & $11,211 \mathrm{a}$ \\
\hline Mean & 0.91 & 0.88 & 2.76 & - & 473.72 \\
CV (\%) & 17.24 & 17.10 & 38.07 & - & 76.70 \\
CVg/CVe & 1.68 & 1.68 & 2.51 & - & 2.44 \\
\hline
\end{tabular}

Means followed by same letters in the columns do not differ by Scott-Knott hierarchical clustering algorithm, at a significance level of 0.05 for the means/grouping test. $\mathrm{CV}=$ environmental coefficient. $\mathrm{CVg} / \mathrm{CV}=$ genotypic and environmental coefficients relation. $\mathrm{GI}=$ Gall Index; EMI= Egg Mass Index ( $0=$ without galls or egg mass; $1=1-2$ galls or egg masses; $2=3-10$ galls or egg masses; $3=11-30$ galls or egg masses; 4= 31-100 galls or egg masses and 5= more than 100 galls or egg masses in the root system) (Taylor \& Sasser, 1978); $\mathrm{Rf}=$ reproduction factor, calculated by dividing the final and initial populations (inoculated); Reaction: degree of resistance $(\mathrm{R}=$ resistant and $\mathrm{S}=$ susceptible) considering resistant the genotypes with $\mathrm{Rf}$ lower than 1 and, susceptible, those that presented $\mathrm{Rf}$ higher or equal to 1 (Oostenbrink, 1966); FWRG $=$ eggs $+\mathrm{J}_{2}$ per root gram part of tuberous root with galls.

Table 2. Reaction of sweet potato genotypes to the infection by Meloidogyne incognita race 1. Brasília, Embrapa, 2019.

\begin{tabular}{lccccc}
\hline Genotype & GI & EMI & Rf & Reaction & FWRG \\
\hline CNPH 1219 & $0.33 \mathrm{~d}$ & $0.33 \mathrm{~d}$ & $0.00 \mathrm{~d}$ & $\mathrm{R}$ & $0.00 \mathrm{e}$ \\
'Coquinho' & $0.17 \mathrm{~d}$ & $0.17 \mathrm{~d}$ & $0.00 \mathrm{~d}$ & $\mathrm{R}$ & $0.00 \mathrm{e}$ \\
CNPH 1392 & $0.33 \mathrm{~d}$ & $0.33 \mathrm{~d}$ & $0.00 \mathrm{~d}$ & $\mathrm{R}$ & $0.00 \mathrm{e}$ \\
CNPH 1292 & $0.17 \mathrm{~d}$ & $0.17 \mathrm{~d}$ & $0.00 \mathrm{~d}$ & $\mathrm{R}$ & $0.00 \mathrm{e}$ \\
CNPH 1358 & $0.00 \mathrm{~d}$ & $0.00 \mathrm{~d}$ & $0.02 \mathrm{~d}$ & $\mathrm{R}$ & $14.12 \mathrm{e}$ \\
CNPH 69 & $0.17 \mathrm{~d}$ & $0.00 \mathrm{~d}$ & $0.03 \mathrm{~d}$ & $\mathrm{R}$ & $12.89 \mathrm{e}$ \\
CNPH 56 & $0.17 \mathrm{~d}$ & $0.33 \mathrm{~d}$ & $0.04 \mathrm{~d}$ & $\mathrm{R}$ & $35.31 \mathrm{e}$ \\
CNPH 02 & $0.00 \mathrm{~d}$ & $0.00 \mathrm{~d}$ & $0.05 \mathrm{~d}$ & $\mathrm{R}$ & $13.41 \mathrm{e}$ \\
CNPH 1361 & $0.00 \mathrm{~d}$ & $0.00 \mathrm{~d}$ & $0.05 \mathrm{~d}$ & $\mathrm{R}$ & $11.39 \mathrm{e}$ \\
CNPH 1202 & $0.00 \mathrm{~d}$ & $0.00 \mathrm{~d}$ & $0.05 \mathrm{~d}$ & $\mathrm{R}$ & $46.53 \mathrm{e}$ \\
CNPH 08 & $0.17 \mathrm{~d}$ & $0.17 \mathrm{~d}$ & $0.08 \mathrm{~d}$ & $\mathrm{R}$ & $20.01 \mathrm{e}$ \\
CNPH 1796 & $0.50 \mathrm{~d}$ & $0.50 \mathrm{~d}$ & $0.10 \mathrm{~d}$ & $\mathrm{R}$ & $90.46 \mathrm{e}$ \\
CNPH 1394 & $0.67 \mathrm{c}$ & $0.67 \mathrm{~d}$ & $0.13 \mathrm{~d}$ & $\mathrm{R}$ & $32.72 \mathrm{e}$ \\
CNPH 1393 & $0.50 \mathrm{~d}$ & $0.50 \mathrm{~d}$ & $0.14 \mathrm{~d}$ & $\mathrm{R}$ & $32.37 \mathrm{e}$ \\
'Brazlândia Roxa' & $0.33 \mathrm{~d}$ & $0.33 \mathrm{~d}$ & $0.15 \mathrm{~d}$ & $\mathrm{R}$ & $30.85 \mathrm{e}$ \\
CNPH 1197 & $1.17 \mathrm{c}$ & $1.17 \mathrm{c}$ & $0.18 \mathrm{~d}$ & $\mathrm{R}$ & $47.90 \mathrm{e}$ \\
CNPH 1232 & $1.00 \mathrm{c}$ & $1.00 \mathrm{c}$ & $0.37 \mathrm{~d}$ & $\mathrm{R}$ & $89.04 \mathrm{e}$ \\
CNPH 05 & $1.00 \mathrm{c}$ & $1.00 \mathrm{c}$ & $0.44 \mathrm{~d}$ & $\mathrm{R}$ & $160.26 \mathrm{e}$ \\
CNPH 60 & $2.00 \mathrm{~b}$ & $2.00 \mathrm{~b}$ & $0.45 \mathrm{~d}$ & $\mathrm{R}$ & $231.41 \mathrm{~d}$ \\
'Rainha' & $2.00 \mathrm{~b}$ & $1.33 \mathrm{c}$ & $0.50 \mathrm{~d}$ & $\mathrm{R}$ & $405.31 \mathrm{~d}$ \\
CNPH 1200 & $0.83 \mathrm{c}$ & $0.83 \mathrm{c}$ & $0.50 \mathrm{~d}$ & $\mathrm{R}$ & $261.43 \mathrm{~d}$ \\
CNPH 1310 & $2.83 \mathrm{a}$ & $2.83 \mathrm{a}$ & $0.73 \mathrm{~d}$ & $\mathrm{R}$ & $591.50 \mathrm{~d}$ \\
'Brazlândia Rosada' & $1.67 \mathrm{~b}$ & $1.17 \mathrm{c}$ & $0.92 \mathrm{~d}$ & $\mathrm{R}$ & $195.23 \mathrm{e}$ \\
CNPH 1220 & $3.00 \mathrm{a}$ & $3.00 \mathrm{a}$ & $1.21 \mathrm{~d}$ & $\mathrm{~S}$ & $2248.3 \mathrm{c}$ \\
CNPH 66 & $1.33 \mathrm{c}$ & $1.33 \mathrm{c}$ & $1.43 \mathrm{~d}$ & $\mathrm{~S}$ & $436.24 \mathrm{~d}$ \\
\hline
\end{tabular}


for example, compose an integrated management system. The highest means for the $\mathrm{Rf}$ of this species were observed in the genotypes CNPH 59, CNPH 1192, CNPH 1221, CNPH 1365, CNPH 1805, CNPH 1809, 'Brazlândia Branca' and 'Princesa', indicating susceptibility to the nematode. The genotype 'Beauregard', with reproduction factor 3.9, was also susceptible to $M$. incognita race 1. Likewise, Cervantes-Flores et al. (2002b) verified the susceptibility of this cultivar to this nematode.

Maluf et al. (1996) evaluated the resistance of 226 sweet potato clones to $M$. javanica and $M$. incognita races 1 , 2, 3 and 4, based on the number of egg masses per root, and observed that the frequencies of resistant genotypes were higher to $M$. javanica and lower to $M$. incognita race 2.

Wanderley \& Santos (2004) studied the resistance of 35 sweet potato cultivars to $M$. incognita, based on reproduction factor, and observed that 15 were resistant. Similarly, Chaves et al. (2013) evaluated the reaction of 25 sweet potato genotypes to $M$. incognita race 2 , based on the reproduction index, and verified that $28 \%$ of the genotypes were slightly resistant; $52 \%$ moderately resistant; $16 \%$ highly resistant and that only one genotype was susceptible.

Massaroto et al. (2010) evaluated the reaction of 50 sweet potatoes accessions to the infection by $M$. incognita race 1 , through the index of egg mass by radicular system, and verified that 15 were highly resistant. Moderate resistance was observed in the cultivar Brazlândia Rosada, corroborating the result found in this work.

Gomes (2014) evaluated the reaction of 63 sweet potato clones to M. incognita races 1 and 3 , based on reproduction factor, and verified that $66.66 \%$ genotypes were resistant to both races. Cultivars Coquinho, Brazlândia Rosada and Brazlândia Branca were resistant to both races. Cultivar Princesa was classified as susceptible. Only cultivar Brazlândia Branca, considered susceptible, presented a different result from that obtained in the present study.

Marchese et al. (2010) evaluated 123 sweet potato genotypes for resistance to $M$. incognita race 1 , based on

Table 2. continuation...

\begin{tabular}{lrrrrr}
\hline Genotype & GI & EMI & Rf & Reaction & FWRG \\
\hline CNPH 46 & $2.17 \mathrm{~b}$ & $2.33 \mathrm{~b}$ & $2.20 \mathrm{~d}$ & $\mathrm{~S}$ & $661.25 \mathrm{~d}$ \\
CNPH 1208 & $2.00 \mathrm{~b}$ & $2.00 \mathrm{~b}$ & $2.28 \mathrm{c}$ & $\mathrm{S}$ & $1789.7 \mathrm{c}$ \\
CNPH 1195 & $2.33 \mathrm{~b}$ & $2.33 \mathrm{~b}$ & $2.50 \mathrm{c}$ & $\mathrm{S}$ & $1637.8 \mathrm{c}$ \\
CNPH 1357 & $2.33 \mathrm{~b}$ & $1.83 \mathrm{~b}$ & $2.74 \mathrm{c}$ & $\mathrm{S}$ & $1942.2 \mathrm{c}$ \\
CNPH 41 & $3.00 \mathrm{a}$ & $3.00 \mathrm{a}$ & $2.74 \mathrm{c}$ & $\mathrm{S}$ & $2436.8 \mathrm{c}$ \\
CNPH 53 & $3.50 \mathrm{a}$ & $3.33 \mathrm{a}$ & $3.10 \mathrm{c}$ & $\mathrm{S}$ & $1502.2 \mathrm{c}$ \\
CNPH 80 & $2.50 \mathrm{~b}$ & $1.00 \mathrm{c}$ & $3.61 \mathrm{c}$ & $\mathrm{S}$ & $2456.3 \mathrm{c}$ \\
'Beauregard' & $1.83 \mathrm{~b}$ & $1.83 \mathrm{~b}$ & $3.90 \mathrm{c}$ & $\mathrm{S}$ & $982.92 \mathrm{~d}$ \\
CNPH 1216 & $3.67 \mathrm{a}$ & $3.67 \mathrm{a}$ & $4.20 \mathrm{c}$ & $\mathrm{S}$ & $3737.2 \mathrm{~b}$ \\
CNPH 1298 & $3.67 \mathrm{a}$ & $3.67 \mathrm{a}$ & $4.25 \mathrm{c}$ & $\mathrm{S}$ & $1638.2 \mathrm{c}$ \\
CNPH 1344 & $3.00 \mathrm{a}$ & $3.00 \mathrm{a}$ & $4.41 \mathrm{c}$ & $\mathrm{S}$ & $2359.3 \mathrm{c}$ \\
'Brazlândia Branca' & $3.50 \mathrm{a}$ & $3.50 \mathrm{a}$ & $5.40 \mathrm{~b}$ & $\mathrm{~S}$ & $706.58 \mathrm{~d}$ \\
'Princesa' & $3.33 \mathrm{a}$ & $3.33 \mathrm{a}$ & $6.00 \mathrm{~b}$ & $\mathrm{~S}$ & $1876.9 \mathrm{c}$ \\
CNPH 1192 & $3.67 \mathrm{a}$ & $3.67 \mathrm{a}$ & $6.05 \mathrm{~b}$ & $\mathrm{~S}$ & $5304.3 \mathrm{~b}$ \\
CNPH 1805 & $3.33 \mathrm{a}$ & $3.17 \mathrm{a}$ & $6.43 \mathrm{~b}$ & $\mathrm{~S}$ & $2004.0 \mathrm{c}$ \\
CNPH 1221 & $2.83 \mathrm{a}$ & $2.83 \mathrm{a}$ & $6.55 \mathrm{~b}$ & $\mathrm{~S}$ & $1053.7 \mathrm{c}$ \\
CNPH 1365 & $2.33 \mathrm{~b}$ & $2.33 \mathrm{~b}$ & $9.82 \mathrm{~b}$ & $\mathrm{~S}$ & $2497.2 \mathrm{c}$ \\
CNPH 59 & $3.33 \mathrm{a}$ & $3.00 \mathrm{a}$ & $10.08 \mathrm{~b}$ & $\mathrm{~S}$ & $3478.3 \mathrm{~b}$ \\
CNPH 1809 & $3.67 \mathrm{a}$ & $3.67 \mathrm{a}$ & $11.02 \mathrm{~b}$ & $\mathrm{~S}$ & $2128.6 \mathrm{c}$ \\
Tomato 'Santa Cruz' & $5.00 \mathrm{a}$ & $4.00 \mathrm{a}$ & $115.2 \mathrm{a}$ & $\mathrm{S}$ & $18134.0 \mathrm{a}$ \\
\hline Mean & 1.81 & 1.7 & 4.89 & - & 1407.4 \\
CV (\%) & 15.26 & 16.03 & 36.24 & - & 60.16 \\
CVg/CVe & 1.72 & 1.61 & 2.23 & - & 1.61 \\
\hline
\end{tabular}

Means followed by same letters in the columns do not differ by Scott-Knott hierarchical clustering algorithm, at a significance level of 0.05 for the means/grouping test. $\mathrm{CV}=$ environmental coefficient. $\mathrm{CVg} / \mathrm{CV}=$ genotypic and environmental coefficients relation. $\mathrm{GI}=$ Gall Index and EMI= Egg Mass Index ( $0=$ without galls or egg masses; $1=1-2$ galls or egg masses; $2=3-10$ galls or egg masses; $3=11-30$ galls or egg masses; $4=31-100$ galls or egg masses and $5=$ more than 100 galls or egg masses in the root system) (Taylor \& Sasser, 1978); $\mathrm{Rf}=$ reproduction factor, calculated by dividing the final and initial populations (inoculated); Reaction: degree of resistance $(\mathrm{R}=$ resistant and $\mathrm{S}=$ susceptible) considering resistant the genotypes with $\mathrm{Rf}$ lower than 1 and, susceptible, those that presented $\mathrm{Rf}$ higher or equal to 1 (Oostenbrink, 1966); FWRG $=$ eggs $+\mathrm{J}_{2}$ per root gram part of tuberous root with galls.

reproduction factor. These authors related 57 resistant genotypes, including cultivar Brazlândia Roxa; 'Brazlândia Branca' was susceptible. However, they classified the cultivar Brazlândia Rosada as susceptible, disagreeing with our results.

Charchar \& Ritschel (2004) evaluated 357 accessions for resistance to the four races of $M$. incognita, according the average number of egg mass, and verified that $79,42,49$ and 40 accessions were infected by races 1, 2, 3 and 4, respectively. Cultivars Brazlândia Roxa and Princesa were highly resistant to all evaluated races, while 'Brazlândia Branca', 'Brazlândia Rosada' and 'Coquinho' were susceptible to race 1 . The responses of cultivars Brazlândia Roxa and Brazlândia Branca were congruent with the results obtained in this work.

Silveira \& Maluf (1993) also evaluated the reaction of 36 sweet potato genotypes to the production of egg masses of races 1, 2, 3 and 4 of M. incognita and verified that 7, 1,9 and 2 genotypes were resistant to these races, respectively. None genotype was simultaneously resistant to the 
four races, indicating independence of resistance sources. About race 1 of $M$. incognita, these authors observed that cultivars Coquinho, Brazlândia Roxa and Brazlândia Branca were susceptible, while cultivar Princesa was resistant. The susceptibility of cultivar Brazlândia Branca is according to the result found in the present work.

\section{Meloidogye enterolobii}

Regarding $M$. enterolobii (Table 3), no galls or egg masses were observed in the root systems of clones CNPH 1292 and CNPH 1392. Except genotypes CNPH 46, CNPH 56, CNPH 60, CNPH 1200, CNPH 1219, CNPH 1221, CNPH 1809 and 'Princesa', all showed indexes greater than 3 (more than 30 galls and/or egg masses per root systems) for these characters. The genotypes CNPH 02, CNPH 05, CNPH 08, CNPH 59, CNPH $66, \mathrm{CNPH} 69, \mathrm{CNPH} 1358, \mathrm{CNPH}$ 1298, CNPH 1192, CNPH 1796, CNPH 1208, CNPH 1216, CNPH 1232, CNPH 1344, CNPH 1361, CNPH 1365, CNPH 1805, 'Rainha', 'Brazlândia Branca' and 'Brazlândia Roxa' presented statistically higher values than the egg mass index obtained on tomato 'Santa Cruz', confirming the high aggressiveness of this pathogen.

Except the genotypes CNPH 46, CNPH 60, CNPH 1200, CNPH 1219 , CNPH 1221, CNPH 1292, CNPH 1392, CNPH 1809, and 'Coquinho', that were resistant to $M$. enterolobii multiplication, and the genotypes $\mathrm{CNPH}$ 1197, CNPH 1202 and 'Princesa', that did not show significant difference compared to the resistant materials; the others were susceptible.

Clone CNPH 1809, with a reproduction factor of 0.52 , was resistant to infection by $M$. enterolobii, although being susceptible to M. javanica and $M$. incognita race 1. Cultivars Brazlândia Roxa and Brazlândia Rosada, which showed resistance to $M$. javanica and $M$. incognita race 1, were susceptible to M. enterolobii. Cultivar Coquinho, with reproduction factor to $M$. enterolobii of 0.40 , was resistant to this species and also to $M$. javanica and $M$. incognita race 1. Cultivars Brazlândia Branca and Princesa were susceptible to $M$. enterolobii and $M$. incognita race 1 ,
Table 3. Reaction of sweet potato genotypes to the infection by Meloidogyne enterolobii. Brasília, Embrapa, 2019.

\begin{tabular}{|c|c|c|c|c|c|}
\hline Genotypes & GI & EMI & Rf & Reaction & FWRG \\
\hline CNPH 1392 & $0.00 \mathrm{~d}$ & $0.00 \mathrm{~d}$ & $0.00 \mathrm{e}$ & $\mathrm{R}$ & $0.00 \mathrm{e}$ \\
\hline CNPH 1292 & $0.00 \mathrm{~d}$ & $0.00 \mathrm{~d}$ & $0.03 \mathrm{e}$ & $\mathrm{R}$ & $73.21 \mathrm{e}$ \\
\hline CNPH 1219 & $0.83 \mathrm{c}$ & $0.67 \mathrm{c}$ & $0.13 \mathrm{e}$ & $\mathrm{R}$ & $77.62 \mathrm{e}$ \\
\hline CNPH 46 & $0.67 \mathrm{c}$ & $1.00 \mathrm{c}$ & $0.24 \mathrm{e}$ & $\mathrm{R}$ & $27.26 \mathrm{e}$ \\
\hline CNPH 60 & $0.50 \mathrm{c}$ & $0.67 \mathrm{c}$ & $0.28 \mathrm{e}$ & $\mathrm{R}$ & $282.74 \mathrm{e}$ \\
\hline CNPH 1221 & $0.67 \mathrm{c}$ & $1.17 \mathrm{c}$ & $0.33 \mathrm{e}$ & $\mathrm{R}$ & $112.63 \mathrm{e}$ \\
\hline 'Coquinho' & $3.17 \mathrm{~b}$ & $3.17 \mathrm{~b}$ & $0.40 \mathrm{e}$ & $\mathrm{R}$ & $1.027 .5 \mathrm{~d}$ \\
\hline CNPH 1809 & $1.33 \mathrm{c}$ & $2.33 \mathrm{~b}$ & $0.52 \mathrm{e}$ & $\mathrm{R}$ & $144.81 \mathrm{e}$ \\
\hline CNPH 1200 & $0.83 \mathrm{c}$ & $1.17 \mathrm{c}$ & $0.83 \mathrm{e}$ & $\mathrm{R}$ & $160.35 \mathrm{e}$ \\
\hline CNPH 1197 & $3.67 \mathrm{~b}$ & $3.67 \mathrm{~b}$ & $1.16 \mathrm{e}$ & $\mathrm{S}$ & $2672.4 \mathrm{~d}$ \\
\hline CNPH 1202 & $3.33 \mathrm{~b}$ & $3.67 \mathrm{~b}$ & $1.65 \mathrm{e}$ & $\mathrm{S}$ & $1955.7 \mathrm{~d}$ \\
\hline 'Princesa' & $2.17 \mathrm{~b}$ & $2.50 \mathrm{~b}$ & $2.53 \mathrm{e}$ & $\mathrm{S}$ & $479.18 \mathrm{e}$ \\
\hline CNPH 56 & $2.83 \mathrm{~b}$ & $2.83 \mathrm{~b}$ & $3.01 \mathrm{~d}$ & $\mathrm{~S}$ & $7830.4 \mathrm{c}$ \\
\hline 'Rainha' & $3.83 \mathrm{a}$ & $4.00 \mathrm{a}$ & $4.04 \mathrm{~d}$ & $\mathrm{~S}$ & $1896.2 \mathrm{~d}$ \\
\hline CNPH 80 & $3.00 \mathrm{~b}$ & $2.67 \mathrm{~b}$ & $4.65 \mathrm{~d}$ & $\mathrm{~S}$ & $5842.8 \mathrm{c}$ \\
\hline CNPH 1310 & $3.83 \mathrm{a}$ & $3.50 \mathrm{~b}$ & $5.17 \mathrm{~d}$ & $\mathrm{~S}$ & $3250.2 \mathrm{~d}$ \\
\hline CNPH 1195 & $2.83 \mathrm{~b}$ & $3.67 \mathrm{~b}$ & $5.60 \mathrm{~d}$ & $\mathrm{~S}$ & $2765.5 \mathrm{~d}$ \\
\hline CNPH 1394 & $3.67 \mathrm{a}$ & $3.67 \mathrm{~b}$ & $6.38 \mathrm{~d}$ & $\mathrm{~S}$ & $4305.0 \mathrm{c}$ \\
\hline 'Beauregard' & $3.00 \mathrm{~b}$ & $3.33 \mathrm{~b}$ & $6.53 \mathrm{~d}$ & $\mathrm{~S}$ & $6293.6 \mathrm{c}$ \\
\hline CNPH 02 & $3.83 \mathrm{a}$ & $4.33 \mathrm{a}$ & $6.57 \mathrm{~d}$ & $\mathrm{~S}$ & $2195.1 \mathrm{~d}$ \\
\hline CNPH 66 & $4.33 \mathrm{a}$ & $4.33 \mathrm{a}$ & $6.85 \mathrm{~d}$ & $\mathrm{~S}$ & $3612.1 \mathrm{c}$ \\
\hline CNPH 1358 & $3.67 \mathrm{a}$ & $4.17 \mathrm{a}$ & $7.18 \mathrm{~d}$ & $\mathrm{~S}$ & $5040.1 \mathrm{c}$ \\
\hline 'Brazlândia Roxa' & $4.17 \mathrm{a}$ & $4.50 \mathrm{a}$ & $9.55 \mathrm{~d}$ & $\mathrm{~S}$ & $2809.0 \mathrm{~d}$ \\
\hline CNPH 1393 & $3.33 \mathrm{~b}$ & $3.33 \mathrm{~b}$ & $9.77 \mathrm{~d}$ & $\mathrm{~S}$ & $13788.3 \mathrm{c}$ \\
\hline CNPH 53 & $3.67 \mathrm{a}$ & $3.67 \mathrm{~b}$ & $9.80 \mathrm{~d}$ & $\mathrm{~S}$ & $7135.2 \mathrm{c}$ \\
\hline CNPH 08 & $4.17 \mathrm{a}$ & $4.33 \mathrm{a}$ & $10.50 \mathrm{c}$ & $\mathrm{S}$ & $3129.8 \mathrm{~d}$ \\
\hline CNPH 1805 & $3.83 \mathrm{a}$ & $4.50 \mathrm{a}$ & $11.24 \mathrm{c}$ & $\mathrm{S}$ & $5840.24 \mathrm{c}$ \\
\hline CNPH 1298 & $3.50 \mathrm{~b}$ & $4.17 \mathrm{a}$ & $12.70 \mathrm{c}$ & $\mathrm{S}$ & $4790.5 \mathrm{c}$ \\
\hline CNPH 1216 & $4.67 \mathrm{a}$ & $4.67 \mathrm{a}$ & $14.05 \mathrm{c}$ & $\mathrm{S}$ & $5254.4 \mathrm{c}$ \\
\hline CNPH 59 & $4.17 \mathrm{a}$ & $4.00 \mathrm{a}$ & $14.22 \mathrm{c}$ & $\mathrm{S}$ & $2715.3 \mathrm{~d}$ \\
\hline 'Brazlândia Branca' & $4.00 \mathrm{a}$ & $4.00 \mathrm{a}$ & $14.33 \mathrm{c}$ & $\mathrm{S}$ & $6264.2 \mathrm{c}$ \\
\hline CNPH 41 & $3.50 \mathrm{~b}$ & $3.67 \mathrm{~b}$ & $15.74 \mathrm{c}$ & $\mathrm{S}$ & $8140.3 \mathrm{c}$ \\
\hline CNPH 1208 & $4.33 \mathrm{a}$ & $4.67 \mathrm{a}$ & $15.87 \mathrm{c}$ & $\mathrm{S}$ & $5600.7 \mathrm{c}$ \\
\hline CNPH 69 & $4.33 \mathrm{a}$ & $4.50 \mathrm{a}$ & $15.93 \mathrm{c}$ & $\mathrm{S}$ & $4449.9 \mathrm{c}$ \\
\hline CNPH 1796 & $4.33 \mathrm{a}$ & $4.50 \mathrm{a}$ & $16.17 \mathrm{c}$ & $\mathrm{S}$ & $7400.9 \mathrm{c}$ \\
\hline CNPH 1344 & $4.17 \mathrm{a}$ & $4.33 \mathrm{a}$ & $16.68 \mathrm{c}$ & $\mathrm{S}$ & $12195.1 \mathrm{~b}$ \\
\hline 'Brazlândia Rosada' & $3.17 \mathrm{~b}$ & $3.50 \mathrm{~b}$ & $21.70 \mathrm{c}$ & $\mathrm{S}$ & $6168.5 \mathrm{c}$ \\
\hline CNPH 1232 & $4.83 \mathrm{a}$ & $5.00 \mathrm{a}$ & $22.57 \mathrm{c}$ & $\mathrm{S}$ & $8995.6 \mathrm{c}$ \\
\hline CNPH 1357 & $4.17 \mathrm{a}$ & $3.67 \mathrm{~b}$ & $23.72 \mathrm{c}$ & $\mathrm{S}$ & $20875.3 \mathrm{~b}$ \\
\hline CNPH 1192 & $4.17 \mathrm{a}$ & $4.17 \mathrm{a}$ & $27.32 \mathrm{~b}$ & $\mathrm{~S}$ & $15977.7 \mathrm{~b}$ \\
\hline CNPH 1365 & $4.50 \mathrm{a}$ & $4.83 \mathrm{a}$ & $30.73 \mathrm{~b}$ & $\mathrm{~S}$ & $8672.4 \mathrm{c}$ \\
\hline
\end{tabular}


Table 3. continuation...

\begin{tabular}{lccccc}
\hline Genotypes & GI & EMI & Rf & Reaction & FWRG \\
\hline CNPH 05 & $4.67 \mathrm{a}$ & $4.50 \mathrm{a}$ & $34.27 \mathrm{~b}$ & $\mathrm{~S}$ & $9531.8 \mathrm{c}$ \\
CNPH 1361 & $4.83 \mathrm{a}$ & $4.67 \mathrm{a}$ & $39.72 \mathrm{~b}$ & $\mathrm{~S}$ & $14717.4 \mathrm{~b}$ \\
CNPH 1220 & $4.00 \mathrm{a}$ & $3.33 \mathrm{~b}$ & $45.87 \mathrm{~b}$ & $\mathrm{~S}$ & $40226.2 \mathrm{a}$ \\
Tomato 'Santa Cruz' & $5.00 \mathrm{a}$ & $3.67 \mathrm{~b}$ & $96.07 \mathrm{a}$ & $\mathrm{S}$ & $12592.8 \mathrm{~b}$ \\
\hline Average & 3.28 & 3.39 & 13.17 & - & 6162.6 \\
CV (\%) & 11.83 & 12.24 & 51.03 & - & 53.94 \\
CVg/CVe & 1.63 & 1.46 & 0.99 & - & 1.04 \\
\hline
\end{tabular}

Means followed by same letters in the columns do not differ by Scott-Knott hierarchical clustering algorithm, at a significance level of 0.05 for the means/grouping test. $\mathrm{CV}=$ environmental coefficient. $\mathrm{CVg} / \mathrm{CV}=$ genotypic and environmental coefficients relation. $\mathrm{GI}=$ Gall Index and EMI $=$ Egg Mass Index $(0=$ without galls or egg masses; $1=1-2$ galls or egg masses; 2=3-10 galls or egg masses; $3=11-30$ galls or egg masses; 4=31-100 galls or egg masses and $5=$ more than 100 galls or egg masses in the root system) (Taylor \& Sasser, 1978); $\mathrm{Rf}=$ reproduction factor, calculated by dividing the final and initial populations (inoculated); Reaction: degree of resistance $(\mathrm{R}=$ resistant and $\mathrm{S}=$ susceptible) considering resistant the genotypes with Rf lower than 1 and, susceptible, those that presented Rf higher or equal to 1 (Oostenbrink, 1966); FWRG $=$ eggs $+\mathrm{J}_{2}$ per root gram part of tuberous root with galls.

but showed resistance to $M$. javanica. Cultivar Coquinho, the only one resistant to both species of nematodes, is an early cycle cultivar having good root yield, is known as resistant to rootknot nematodes, but presents irregular root shape, ranging from elongated to rounded, pale yellow and unattractive peel; therefore, not widely cultivated, but it could be an alternative to compose an integrated management system in areas infested with root-knot nematodes, or to be used in crossings.

Melo et al. (2011) evaluated the resistance of eight sweet potato genotypes to $M$. enterolobii. The authors verified that cultivars Brazlândia Rosada, Brazlândia Roxa and Brazlândia Branca were susceptible and that only two genotypes were resistant, UFLA0749 and UFLA0753. According to these authors, due to the existence of susceptible genotypes to $M$. enterolobii but resistant to other rootknot nematode species, indicate that the resistance to M. enterolobii, apparently, is mediated by genes other than those that confer resistance to other species of Meloidogyne.

Gonçalves (2011) studied 142 sweet potato clones to the resistance to $M$. enterolobii and found 30 resistant genotypes. In that study, cultivars Brazlândia Rosada, Brazlândia Roxa and Brazlândia Branca were also susceptible.

Although several studies found in the literature about sweet potato genotype's reaction to root-knot nematodes, there exist few information related to $M$. enterolobii. In the present study many new accessions were evaluated, which provide more options to breeders; but even for those coincident accessions, different results in some researches were verified. These differences may be due to the concept of resistance that, in some cases, is determined by the egg mass index or by the gall visualization and, in some cases, by the reproduction factor. Moreover, experimental factors as temperature, the time the roots remain in the soil before inoculation, the planting date, the life cycle of the nematode, the population density and the stage of development of the root system can interfere in the nematode multiplication and, as a consequence, in the resistance expression (Lawrence et al., 1986). So, even for genotypes evaluated in earlier works, it is important to study the genotypes to confirm or not the resistance pattern, and to define whether these genotypes are resistant to other species of nematodes. About the parameters and concepts, the best parameter to assess resistance is based on the Reproduction Factor, according Oostenbrink. Regarding the Gall Index and Egg Mass Index, these are variables used to assist the interpretation of the $\mathrm{Rf}$ values.

The fact that the evaluated cultivars, that are widely cultivated, have been susceptible, mainly to $M$. incognita and $M$. enterolobii, and the existence of resistant accessions, reinforce the importance of studies like this, to support sweet potato breeding programs. $M$. javanica was the least aggressive species, infecting and reproducing only $9.09 \%$ of the studied genotypes. Race 1 of $M$. incognita reproduced in $47.73 \%$ of the genotypes. M. enterolobii was the most aggressive species, having as susceptible hosts $79.55 \%$ of the evaluated genotypes. Genotypes $\mathrm{CNPH}$ 1200, CNPH 1219, CNPH 1292, CNPH 1392, CNPH 60 and 'Coquinho' were resistant to $M$. javanica, $M$. incognita race 1 and $M$. enterolobii, being good sources of resistant genes to the three nematode species.

\section{REFERENCES}

ATKINSON, HJ; LILLEY, CJ; URWIN, PE. 2012. Strategies for transgenic nematode control in developed and developing world crops. Current Opinion in Biotechnology 23: 251-256.

BERNARD, GC; EGNIN, M; BONSI, C; MORTLEY, D; WITOLA, WH; McELHENNEY, W.; LAWRENCE, K. 2017. Evaluation of root-knot nematode resistance in sweet potato. African Journal of Agricultural Research 12: 1411-1414.

BONETI, JIS; FERRAZ, S. 1981. Modificação do método de Hussey \& Barker para extração de ovos de Meloidogyne exigua de raízes de cafeeiro. Fitopatologia Brasileira 6: 553.

CARNEIRO, RMDG; ALMEIDA, MRA. 2001. Técnica de eletroforese usada no estudo de enzimas dos nematoides de galhas para identificação de espécies. Nematologia Brasileira 25: 35-44.

CARNEIRO, RMDG; ALMEIDA, MRA; BRAGA, RS; ALMEIDA, CA; GIORIA, R. 2006a. Primeiro registro de Meloidogyne mayaguensis parasitando plantas de tomate e pimentão resistentes à meloidoginose no estado de São Paulo. Nematologia Brasileira 30: 81-86.

CARNEIRO, RMDG; MÔNACO, APA; MORITZ, MP; NAKAMURA, KC; SCHERER, A. 2006b. Identificação de Meloidogyne mayaguensis em goiabeira e em plantas invasoras, em solo argiloso, no Estado do Paraná. Nematologia Brasileira 30: 293-298.

CERVANTES-FLORES, JC; YENCHO, GC; DAVIS, EL. 2002a. Efficient evaluation of resistance to three root-knot nematode species in selected sweetpotato cultivars. HortScience 
37: 390-392.

CERVANTES-FLORES, JC; YENCHO, GC; DAVIS, EL. 2002b. Host reactions of sweet potato genotypes to root-knot nematodes and variation in virulence of Meloidogyne incognita populations. HortScience 37: 1112-1116.

CHARCHAR, JM; RITSCHEL, PS. 2004. Avaliação do banco de germoplasma de batata-doce da Embrapa Hortaliças para resistência a Meloidogyne spp. Brasília: Embrapa Hortaliças. Boletim de Pesquisa e Desenvolvimento 03, 28 p.

CHAVES, PPN; SANTOS, GR; SILVEIRA, MA; GOMES, LAA; MOMENTÉ, VG; NASCIMENTO, IR. 2013. Reação de genótipos de batata-doce a nematoides de galhas em condições de temperatura elevada. Bioscience Journal 29: 1869-1877.

CRUZ, CD. 2013. GENES - a software package for analysis in experimental statistics and quantitative genetics. Acta Scientiarum 35: 271-276.

EISENBACK JD; HIR SCHMANNTRIANTAPHYLLOU H. 1991. Root-knot nematodes: Meloidogyne species and races. In: NICKLE, WR (ed). Manual of Agricultural Nematology New York. p.191-274.

EPPO. 2014. Meloidogyne enterolobii. EPPO Bulletin 44: 159-163.

GOMES, JAA. 2014. Resistência de clones de batata-doce a nematoides (Meloidogyne spp.). Diamantina: UFVJM. 79p. (M.Sc. dissertation).

GOMES, JAA; ANDRADE JÚNIOR, VC; OLIVEIRA, CMD; AZEVEDO, AM; MALUF, WR; GOMES, LAA. 2015. Resistance of sweet potato clones to Meloidogyne incognita races 1 and 3. Bragantia 74: 291-297.
GONÇALVES, RJS. 2011. Variabilidade genética para produção de etanol e para resistência a Meloidogyne enterolobii em coleção de clones de batata-doce. Lavras: UFLA. 110p. (Ph.D. thesis).

KARURI, HW; OLAGO, D; NEILSON, R; MARARO, E; VILLINGER, J. 2017. A survey of root-knot nematodes and resistance to Meloidogyne incognita in sweet potato varieties from Kenyan fields. Crop Protection 92: 114-121.

LAWRENCE, GW; CLARK, CA; WRIGHT, VL. 1986. Influence of Meloidogyne incognita on resistant and susceptible sweet potato cultivars. Journal of Nematology 18: 59-65.

MALUF, WR; AZEVEDO, SM; CAMPOS, VP. 1996. Heritability of root-knot nematode (Meloidogyne spp.) resistance in sweet potatoes. HortScience 31: 622-622.

MARCHESE, A; MALUF, WR; GONÇALVES NETO, AC; GONÇALVES, RJS; GOMES, LAA. 2010. Seleção de clones de batata-doce resistentes a Meloidogyne incognita raça 1. Pesquisa Agropecuária Brasileira 45: $997-$ 1004.

MASSAROTO, JA; GOMES, LAA; MALUF, WR; SILVA, RR; GOMES, ARVA. 2010. Reação de clones de batata-doce ao Meloidogyne incognita raça 1. Revista de Ciências Agro-Ambientais 8: 1-8.

MELO, OD; MALUF, WR; GONÇALVES, RJS; GONÇALVES NETO, AC; GOMES, LAA; CARVALHO, RC. 2011. Screening vegetable crop species for resistance to Meloidogyne enterolobii. Pesquisa Agropecuária Brasileira 46: 829-835.

OOSTENBRINK, M. 1966. Major characteristics of the relation between nematodes and plants.
Mededelingen Van De Landbouwhogeschool Te Wageningen, 66: 1-46.

PERRY, RN; MOENS, M (ed). 2006. Plant Nematology. Cambridge, MA: CABI.

PIEDRA-BUENA, A; LÓPEZ-PÉREZ, JA; DÍEZROJO, MA; ROBERTSON, L; CASTROLIZAZO, I; BELLO, A. 2011. Screening of three sweet potato (Ipomoea batatas L.) cultivars for resistance to different virulence groups of root-knot nematodes (Meloidogyne spp.) under controlled conditions. Crop Protection 30: 134-140.

RAMMAH A; HIRSCHMANN H. 1988. Meloidogyne mayaguensis n. sp. (Meloidogynidae), a root-knot nematode from Puerto Rico. Journal of Nematology 20: 58-69.

RUTTER, W; SKANTAR, AM; HANDOO, ZA; MUELLER, JD; AULTMAN, SP; AGUDELO, P. 2019. Meloidogyne enterolobii found infecting root-knot nematode resistant sweet potato in South Carolina, United States. Plant Disease. Available $<$ https://apsjournals. apsnet.org/doi/10.1094/PDIS-08-18-1388PDN>. Accessed March 14, 2019.

SILVEIRA, M; MALUF, WR. 1993. Resistência de clones de batata-doce a Meloidogyne spp. Horticultura Brasileira 11: 131-133.

TAYLOR, AL; SASSER, JN. 1978. Biology, identification and control of root-knot nematodes (Meloidogyne species). Raleigh: North Carolina State University Graphics, $111 \mathrm{p}$.

WANDERLEY, MJ; SANTOS, JM. 2004. Resistência de cultivares de batata-doce a Meloidogyne incognita. Fitopatologia Brasileira 29: 437-440.

YANG B; EISENBACK, JD. 1983. Meloidogyne enterolobii sp. (Meloidogynidae), a root-knot nematode parasitising pacara earpod tree in China. Journal of Nematology 15: 381-391. 